(c) American Dairy Science Association, 2004.

\title{
Persistency of Adenoviral-Mediated Lysostaphin Expression in Goat Mammary Glands
}

\author{
W. Fan, K. Plaut, A. J. Bramley, J. W. Barlow, \\ S. A. Mischler, and D. E. Kerr \\ Department of Animal Science \\ College of Agriculture \& Life Sciences \\ University of Vermont, Burlington 05405
}

\section{ABSTRACT}

Gene therapy has great potential to enable synthesis of protein molecules in targeted cells of an animal. One application may be the production of antibacterial enzymes by the mammary gland as a means of preventing or treating mastitis. We have previously demonstrated that goat mammary cells are capable of producing lysostaphin, an antistaphylococcal enzyme, after being transduced in vivo with a recombinant adenoviral vector containing a modified lysostaphin gene (Ad-lys). The current study examined duration of expression, and antibody response to lysostaphin and the adenoviral vector. Following intramammary infusion into nonlactating goats $(n=4)$, recovery of transducible adenoviral vector in mammary secretions persisted for $11 \mathrm{~d}$. Transducible vector was not detected in serum, saliva, urine, or feces. Peak lysostaphin concentrations $(<20 \mu \mathrm{g} / \mathrm{mL})$ in mammary secretions of infused udders were detected approximately 1 wk postinfusion, and generally returned to undetectable levels after an additional 1 to 2 wk. The poor persistency of expression was likely due to the very potent immune response to both the adenovirus and the expressed lysostaphin. Serum IgG antibodies recognizing the adenoviral vector developed within $7 \mathrm{~d}$ of the infusion, and titers rose dramatically to greater than $1: 1 \times 10^{5}$. Similar titers of serum IgG antibodies to lysostaphin developed in 3 goats, with more moderate titers in the fourth goat. The antibody response to lysostaphin was delayed by approximately $4 \mathrm{~d}$ in comparison to the response to the adenovirus. Serum IgG antibody profiles were reflected in mammary secretions. No IgA antibodies to adenovirus or lysostaphin were detected in sera or mammary secretion. We demonstrate that while the lysostaphin gene can be introduced to the mammary gland using an adenoviral-mediated gene transfer technique, the strong

Received June 9, 2003.

Accepted August 25, 2003

Corresponding author: D. E. Kerr; e-mail: dkerr@zoo.uvm.edu. immune response that it provokes makes the approach unsuitable for combating mastitis.

(Key words: adenovirus, lysostaphin, mastitis, antibody)

Abbreviation key: Ad-lac Z = adenoviral vector containing the E.coli lac $Z$ gene, Ad-lys = adenoviral vector containing a modified lysostaphin gene, BAV-3 = bovine adenovirus type 3, BHV-1 = bovine herpesvirus type 1, HD-Ad = helper-dependent adenoviral vector, FIX = factor IX, $\mathbf{g D}=$ glycoprotein D, PBS-T $=$ PBS- $0.1 \%$ Tween 20, PBS-T-G = PBS-0.1\% Tween 20-0.1\% gelatin.

\section{INTRODUCTION}

Intramammary infections are of great detrimental burden to the dairy industry. While there are numerous mastitis-causing pathogens, Staphylococcus aureus is one of the most frequently isolated bacterial pathogens and often results in a chronic state of infection (Nordhaug et al., 1994). Current strategies to protect against $S$. aureus mastitis rely on preventative hygiene, prophylactic and therapeutic use of antibiotics, and ultimately on removal of infected animals from the herd. New strategies are being explored with the goal of providing the cells of the mammary gland with a new gene that will enable them to produce the antistaphylococcal enzyme, lysostaphin ( Kerr et al., 2001; Fan et al., 2002). Lysostaphin has a potent staphylolytic activity and has been shown to be an effective therapy in experimentally induced murine and bovine mastitis (Bramley and Foster, 1990; Oldham and Daley, 1991; Ulmer et al., 1993). In a previous study (Fan et al., 2002), we demonstrated that a recombinant, replication-deficient human adenoviral vector containing a modified lysostaphin gene (Kerr et al., 2001) could transduce bovine mammary epithelial cells in vitro and goat teat canal epithelium in vivo. Bioactive lysostaphin was detected in mammary secretions; however, as part of the experimental design, the animals were euthanized after $2 \mathrm{~d}$ for evaluation of the mammary tissue. The objective of the current study was to measure the persistency of intact viral 
particles in mammary secretions, the duration of lysostaphin expression, and to determine whether an antibody response was stimulated by the procedures.

Adenoviral-mediated gene transfer has been used experimentally to deliver a variety of exogenous genes to various target cells in vivo as a prelude to correcting hereditary deficiencies of functional proteins such as cystic fibrosis transmembrane conductance regulator (Engelhardt et al., 1993), ornithine transcarbamylase (Ye et al., 1996), human factor IX (FIX) (Dai et al., 1995), human factor VIII (Connelly et al., 1996), and dystrophin (Clemens et al., 1996). Poor persistence of transgene expression and marked host immune responses against both the adenovirus and/or the transgene products have been observed in most adenoviral-mediated gene transfer experiments (Xiang et al., 1996; Yang et al., 1996). The host immune response diminishes the persistence of transgene expression, but a number of reports indicate that expression of the foreign protein may last a few months (Connelly et al., 1996; Ye et al., 1996). This length of time, for mammary expression of lysostaphin, may be suitable for protection of cows against staphylococcal infection during the mastitis susceptible nonlactating period between lactations, or as a means to protect animals prior to their first lactation.

\section{MATERIALS AND METHODS}

\section{Transduction of Goat Mammary Gland Cells in Vivo}

Replication-deficient adenoviruses containing either the E.coli lacZ gene (Ad-lacZ) or a modified version of the $S$. simulans lysostaphin gene (Ad-lys) were previously described (Fan et al., 2002). The vectors were constructed from the pAvS6a shuttle plasmid (Smith et al., 1993) and an E3 deletion mutant of human adenovirus type 5 (Ad-d1327). The resulting E1-, E3-deleted, replication-deficient adenoviruses were propagated in the human adenovirus type 5 transformed 293 packaging cell line (CRL 1753, American Type Culture Collection, Manassas, VA) and purified by density gradient ultracentrifugation (Rosenfeld et al., 1992). Four nonlactating, multiparous, Toggenburg goats were purchased locally and housed individually in metabolism crates for a 2-d acclimation period and for $14 \mathrm{~d}$ following intramammary infusion. After $14 \mathrm{~d}$ the crates allowed for total collection of urine and feces that were subsequently autoclaved before disposal or incinerated. The goats were then group housed in an $18-\mathrm{m}^{2}$ pen with straw bedding that was subsequently disposed of in typical agricultural practice. At all times the animals had free access to feed and water. During the trial, for all mammary infusions and sample collections, teats were routinely prewiped with alcohol and postdipped with iodine to prevent mammary gland infection. Housing and care was conducted in accordance with the Office of Animal Care Management, following approval by the University of Vermont IACUC.

On d 0 , after collecting preinfusion samples (blood, urine, feces, saliva, and mammary gland secretions), the right teat of four goats received $5 \mathrm{~mL}$ of $2 \times 10^{10}$ $\mathrm{pfu} / \mathrm{mL}$ Ad-lys in infusion diluent $(10 \mathrm{~m} M$ Tris $\mathrm{pH7.4}$, $1 \mathrm{mM} \mathrm{MgCl}$, with $10 \%$ glycerol). Left teats received 5 $\mathrm{mL}$ of $2 \times 10^{10} \mathrm{pfu} / \mathrm{mL}$ Ad-lac $Z$ (three goats) or $5 \mathrm{~mL}$ of infusion diluent (Archer et al., 1994) as a negative control. Blood, urine, feces, saliva, and mammary gland secretions were collected on d $2,4,7,11,14,21,28,35$, and 42 post-infusion. On $d 42$ the goats were euthanized. All mammary secretion samples were examined for bacteriological contamination and SCC by the University of Vermont's Quality Milk Research Laboratory.

\section{Detection of Transducible Adenovirus in Goat Secretions}

The presence of transducible Ad-lac $Z$ particles in test samples was monitored by $\beta$-galactosidase expression in replication permissive 293 cells exposed to the samples. Sample transduction medium was prepared by adding $50 \mu \mathrm{L}$ of sample (either mammary gland secretion, serum, urine, or dissolved feces) to $450 \mu \mathrm{L}$ of medium containing $2 \%$ fetal bovine serum (GIBCO, Grand Island, NY). Saliva samples collected on cotton-tipped applicator swabs were immersed into $500 \mu \mathrm{L}$ of transduction medium. A series of standards containing known quantities of transducible adenoviral particles was used to monitor transduction efficiency and to estimate the concentration of transducible adenovirus in the samples. Confluent monolayers of 293 cells cultured in 6 -well dishes were incubated with $500 \mu \mathrm{L}$ of either standard or sample transduction medium (Fan et al., 2002). After exposure for $1.5 \mathrm{~h}$ at $37^{\circ} \mathrm{C}$ in a $5 \% \mathrm{CO}_{2}$ atmosphere, complete medium (10\% FBS) was added and the cells were incubated for $24 \mathrm{~h}$ to allow production of $\beta$-galactosidase. Detection of the $\beta$-galactosidase was then performed (Fan et al., 2002).

\section{Analysis of Lysostaphin in Mammary Gland Secretions}

Immunological lysostaphin concentrations in mammary secretions were determined by ELISA and bioactive concentrations determined by staphylolytic assay (Fan et al., 2002). Recombinant lysostaphin (Sigma) was used as standard. 


\section{Detection of Antibodies in Sera and Mammary Gland Secretions}

Antibodies to adenovirus and lysostaphin in sera and mammary gland secretions were detected by indirect ELISA. A dilution series of serum samples were prepared in PBS containing $0.1 \%$ Tween 20 and $0.1 \%$ gelatin (PBS-T-G). Mammary secretion samples were analyzed for total protein (Bio-Rad, Richmond, CA) then initially diluted in PBS-T-G to a protein concentration of $25 \mu \mathrm{g} / \mathrm{mL}$. A subsequent dilution series was then prepared in PBS-T-G for analysis. The diluted serum and secretion samples were stored at $4^{\circ} \mathrm{C}$ for $12 \mathrm{~h}$. High binding EIA/RIA plates (Corning) were coated with recombinant lysostaphin $(1 \mu \mathrm{g} / \mathrm{mL})$ or Ad-lac $Z$ ( $5 \mu \mathrm{g}$ of protein $/ \mathrm{mL}$ ) in $0.05 \mathrm{M}$ sodium carbonate buffer ( $\mathrm{pH} 9.6$ ) at $4^{\circ} \mathrm{C}$ for $12 \mathrm{~h}$. These plates were washed three time with PBS containing $0.1 \%$ Tween 20 (PBS-T) and blocked with PBS-T-G at room temperature for $1 \mathrm{~h}$. The plates were washed and incubated for $2 \mathrm{~h}$ with $100 \mu \mathrm{L}$ of diluted serum or mammary secretion. After incubation the plates were washed with PBS-T and incubated for $2 \mathrm{~h}$ at room temperature with anti-goat IgG or IgA, peroxidase conjugate (Sigma) diluted in PBS-T at dilution factors of 10,000 (for serum samples) or 20,000 (for mammary secretions). Plates were then washed and bound enzyme was detected by color development $\left(\mathrm{OD}_{405}\right)$ following addition of $3,3^{\prime}, 5,5^{\prime}$ tetramethylbenzidine dihydrochloride (Sigma, St. Louis, MO). Preinfusion values were considered as background and were subtracted from values obtained from postinfusion samples. Antibody titer was defined as the highest dilution of the sample that gave $\mathrm{OD}_{405}$ values twice that of the background.

\section{RESULTS}

The goat teats appeared normal during the experiment period with the exception of moderate swelling on $\mathrm{d} 2$ in two of the four goats. The swelling in one goat disappeared by $\mathrm{d} 4$, and in the other by $\mathrm{d} 14$. A mild coagulase-negative staphylococcal infection was detected in the left teat of one goat preinfusion, which persisted until the end of experiment. No bacterial infection was detected in other glands prior to or during the experiment.

\section{Presence of Viable Ad-lacZ Virus in Secretion Samples}

At no time following intramammary vector infusion was Ad-lac $Z$ detectable in the saliva, serum, urine, or feces. However, Ad-lac $Z$ was detectable in mammary secretions from all Ad-lac $Z$ treated glands until d 11. An approximation of the Ad-lac $Z$ particle concentrations in

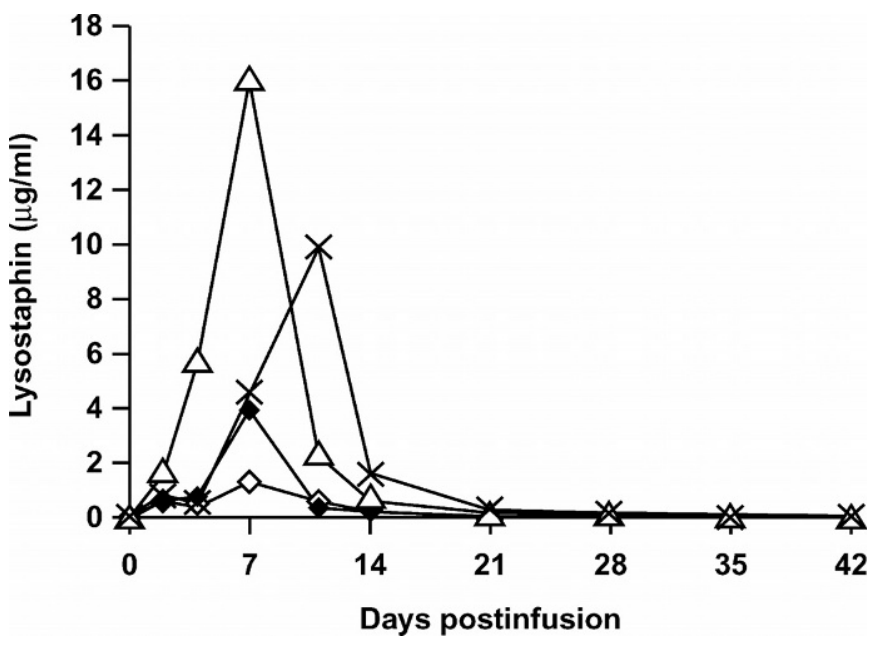

Figure 1. Lysostaphin concentrations in mammary secretions obtained from glands of four goats following intramammary infusion of adenovirus $\left(10^{11} \mathrm{pfu} / \mathrm{gland}\right)$ containing the lysostaphin gene (goat $\mathrm{A}, \diamond$; goat $\mathrm{B}, \diamond$; goat $\mathrm{C}, \triangle$; goat $\mathrm{D}, \times)$.

secretions was determined by comparing the numbers of $L a c Z$-expressing 293 cells resulting from exposure to dilutions of mammary secretions with the numbers of $L a c Z$-expressing cells resulting from exposure to known quantities of virus. Ad-lac $Z$ particle concentrations in the mammary secretions were approximately $10^{9}, 10^{7}$, and $10^{5} \mathrm{pfu} / \mathrm{mL}$ on $\mathrm{d} 2,4$, and 7 , respectively, with no particles detectable on d 11 .

\section{Lysostaphin in Mammary Gland Secretions}

Lysostaphin was not detectable in non Ad-lys treated mammary gland secretions. Lysostaphin expression in Ad-lys treated glands increased gradually after infusion and peaked at $\mathrm{d} 7$ (3 goats) or 11, then declined dramatically (Figure 1). The lysostaphin concentrations returned to basal levels in 3 goats after $14 \mathrm{~d}$ and by d 21 in the fourth goat. Examination of the ELISA used to quantitiate lysostaphin indicated that detection of lysostaphin added to preinfusion secretion $(10 \mu \mathrm{g} / \mathrm{mL})$ was $92 \%$, while detection of lysostaphin added to postinfusion secretion ranged from 28 to $90 \%$. The assay interference was likely due in part to antibodies to lysostaphin that were present in the postinfusion secretions (see below). Consequently, lysostaphin concentrations are underestimated by ELISA in postinfusion secretion. The highest lysostaphin bioactivity, observed as a zone of lysis on a lawn of $S$. aureus, was $0.1 \mu \mathrm{g} / \mathrm{mL}$ (data not shown). Some reduction in bioactivity as compared with immunoreactivity was expected as the modified lysostaphin produced by mammalian cells has previously been shown to have approximately $20 \%$ of the activity of the recombinant, bacterially produced form (Kerr et 


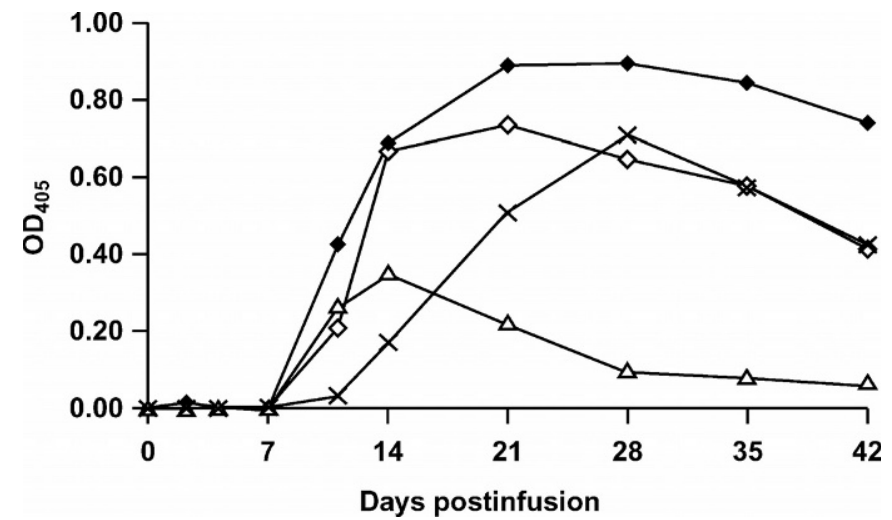

Figure 2. Serum anti-lysostaphin IgG in 1:1000 dilute samples obtained from four goats following intramammary infusion of adenovirus $\left(10^{11} \mathrm{pfu} / \mathrm{gland}\right)$ containing the lysostaphin gene (symbols for each animal as in Figure 1).

al., 2001; Fan et al., 2002). The substantial reduction bioactivity may be related to the presence of neutralizing antibodies in the secretion samples.

\section{Antibody Response to Lysostaphin and to Adenovirus}

Serum IgG reactive to lysostaphin was observed in all animals $11 \mathrm{~d}$ after the infusion of Ad-lys, and in 3 animals the levels remained elevated for the entire 42$d$ duration of the experiment (Figure 2). Serum antibody titers to lysostaphin reached 1:50,000 or greater in 3 of the 4 goats (Table 1). A more moderate titer of 1:1600 developed in the fourth goat. Anti-lysostaphin titers in mammary secretions were similar. Of note is that the animal with the lowest anti-lysostaphin response achieved the greatest lysostaphin concentrations in mammary secretions. Also, the titers in both glands were similar even though the Ad-lys was only infused into the right-hand gland.

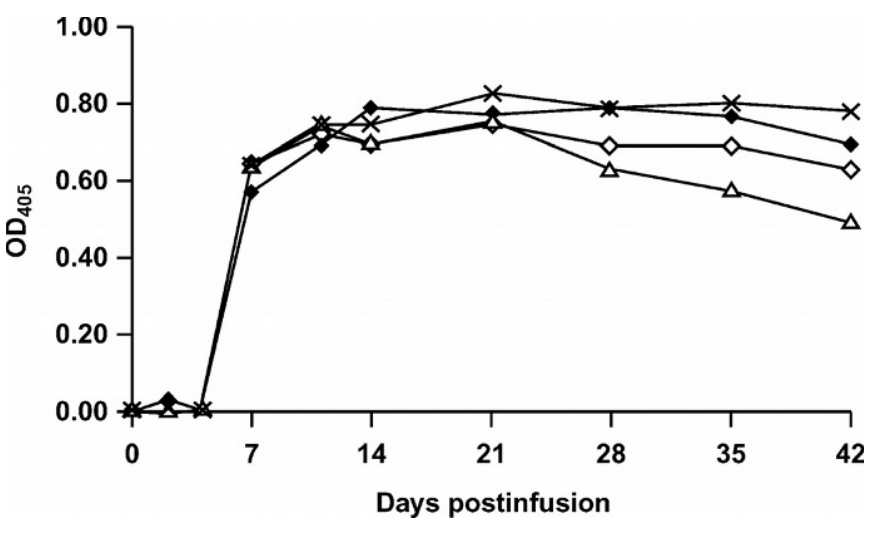

Figure 3. Serum anti-adenovirus IgG in 1:5000 dilute samples obtained from four goats following intramammary infusion of adenovirus. Adenovirus containing either the lysostaphin gene or the $l a c Z$ gene was infused into each gland with $\left(10^{11} \mathrm{pfu} / \mathrm{gland}\right)$, except for goat $\mathrm{D}$, which only received adenovirus containing the lysostaphin gene in one gland and diluent in the other (goat $\mathrm{A}, \diamond$; goat $\mathrm{B}, \diamond$; goat $\mathrm{C}, \triangle$; goat $\mathrm{D}, \times)$.

The serum antibody response to adenovirus was also substantial, but developed even more rapidly than the anti-lysostaphin response and was consistent in all 4 animals (Figure 3). Within $7 \mathrm{~d}$ of the infusion, a marked anti-adenovirus response was detected in all animals. In comparison, the anti-lysostaphin response required 14 to $21 \mathrm{~d}$ to fully develop. Serum IgG titers to adenovirus of 1:800,000 were consistently detected (Table 1). Similar titers were also detected in mammary secretions. Antibodies of the IgA isotype against either adenovirus or lysostaphin were not found in goat sera or mammary secretions.

\section{DISCUSSION}

We have previously reported transduction of cells lining the teat cistern in Ad-lacZ infused goat mammary glands, and the presence of lysostaphin in mammary

Table 1. Maximium antibody titers in goat sera and mammary secretion samples obtained over a 42-d period following intramammary infusion of adenovirus. The right gland in all goats was infused with adenovirus containing the lysostaphin gene $\left(10^{11} \mathrm{pfu} / \mathrm{gland}\right)$. The left gland in goats $\mathrm{A}, \mathrm{B}, \mathrm{C}$ was infused with adenovirus containing the lac- $Z$ gene $\left(10^{11} \mathrm{pfu} / \mathrm{gland}\right)$, while the left gland of goat $\mathrm{D}$ was infused with diluent. Antibody titers represent the largest dilution of sample resulting in assay $\mathrm{OD}_{405}$ values of twice of the background.

\begin{tabular}{|c|c|c|c|c|c|c|}
\hline \multirow[b]{2}{*}{ Goat } & \multicolumn{2}{|c|}{ Serum antibody titers } & \multicolumn{2}{|c|}{$\begin{array}{l}\text { Left mammary gland } \\
\text { secretion antibody titers }\end{array}$} & \multicolumn{2}{|c|}{$\begin{array}{l}\text { Right mammary gland } \\
\text { secretion antibody titers }\end{array}$} \\
\hline & $\begin{array}{c}\text { Anti- } \\
\text { adenovirus }\end{array}$ & $\begin{array}{c}\text { Anti- } \\
\text { lysostaphin }\end{array}$ & $\begin{array}{c}\text { Anti- } \\
\text { adenovirus }\end{array}$ & $\begin{array}{c}\text { Anti- } \\
\text { lysostaphin }\end{array}$ & $\begin{array}{c}\text { Anti- } \\
\text { adenovirus }\end{array}$ & $\begin{array}{c}\text { Anti- } \\
\text { lysostaphin }\end{array}$ \\
\hline A & 800,000 & 100,000 & 800,000 & 100,000 & 800,000 & 800,000 \\
\hline B & 800,000 & 100,000 & 800,000 & 100,000 & 800,000 & 800,000 \\
\hline $\mathrm{C}$ & 800,000 & 1600 & 800,000 & 6400 & 800,000 & 6400 \\
\hline $\mathrm{D}$ & 800,000 & 50,000 & 800,000 & 3200 & 800,000 & 400,000 \\
\hline
\end{tabular}


secretions of Ad-lys infused glands (Fan et al., 2002). In that study, the animals were infused with $1 \mathrm{~mL}$ of solution containing $1.5 \times 10^{10} \mathrm{pfu}$ of Ad-lys, and were euthanized $48 \mathrm{~h}$ postinfusion for tissue collection and examination. We have now examined an extended time course of lysostaphin production following transduction with the same recombinant adenovirus but administered at a higher dose of $5 \mathrm{~mL}$ of $2 \times 10^{10} \mathrm{pfu} / \mathrm{mL}$. The higher dose had minimal effect on the average concentration of lysostaphin in mammary secretions obtained $48 \mathrm{~h}$ postinfusion that was approximately $1 \mu \mathrm{g} / \mathrm{mL}$ in both studies. Further studies would be required to determine whether the number of epithelial cells transduced differed in the two studies. As adenoviral DNA generally does not integrate into the host cell chromosome, we expected only transient expression of the lysostaphin gene. However, a number of reports indicate that expression can persist for 1 to 2 mo (Connelly et al., 1995, 1996; Chen et al., 1997), which may be ideal for short-term protection of the mammary gland from $S$. aureus infection.

In the current study we have found that although lysostaphin concentrations in mammary secretion increase until approximately $7 \mathrm{~d}$ posttransduction, the persistency of lysostaphin production was relatively short-lived. Lysostaphin concentrations approached nondetectable levels $21 \mathrm{~d}$ postinfusion. The peak concentrations observed were on average less than $10 \mu \mathrm{g} /$ $\mathrm{mL}$, and only limited bioactivity could be detected. The native form of lysostaphin has very potent staphylolytic activity that can easily be detected at a concentration of $0.01 \mu \mathrm{g} / \mathrm{mL}$. The lysostaphin encoded by the adenovirus has been modified by 2 amino acid substitutions to enable production of an active form by mammalian cells (Kerr et al., 2001). The modified form has approximately $20 \%$ of the activity of the native form. Our inability to detect more bioactivity in the secretions was likely due to neutralizing antibodies in the secretions. It seems unlikely that the moderate level of lysostaphin produced in the current study would be of benefit in preventing $S$. aureus mastitis.

An aggressive immune response to both lysostaphin, and the adenoviral vector undoubtedly contributed to the short-lived ability of the transduced cells to produce lysostaphin. This was reflected by the apparent inverse relationship between the profiles of lysostaphin concentrations in mammary secretions and the serum titers of anti-lysostaphin IgG. For 3 of the goats, lysostaphin concentrations in mammary secretions reached peak at d 7 , while serum antibodies to lysostaphin were still undetectable. Between d 7 and 11, the antibody levels climbed, while lysostaphin concentration in secretions dropped dramatically. A similar response, albeit delayed, was observed in the fourth goat. Of note is the finding that the goat whose mammary secretions obtained the highest concentration of lysostaphin was also the goat with the lowest lysostaphin antibody titers. The potent immune response to lysostaphin was unexpected in consideration of a previous study in cattle that showed minimal antibody response in animals given up to 27 intramammary infusions of recombinant lysostaphin over a 9-mo period (Daley and Oldham, 1992). These authors concluded that the intramammary administration of recombinant lysostaphin to the bovine was relatively nonimmunogenic. However, in the present study, lysostaphin was synthesized within the transduced cells of the animals as opposed to exogenous delivery of protein. In agreement with the present study, a substantial anti-human FIX response was observed in monkeys following intravenous administration of an adenoviral vector encoding FIX, whereas a much lower response was produced by administering the purified protein (Lozier et al., 1999). Endogenous synthesis of foreign proteins is known to stimulate both humoral and cell-mediated immune responses, and has been demonstrated in numerous studies exploiting this finding in the development of DNA-based vaccines (Donnelly et al., 1997).

Poor persistence of transgene expression and substantial host immune responses are related. The importance of the immune response in limiting transgene expression has been clearly demonstrated in mice injected with adenoviral vectors containing the canine FIX gene. In one study, Dai et al. (1995) injected mouse legs with adenoviral vectors containing the FIX gene and analyzed FIX production in mouse plasma by ELISA. They found that FIX concentrations peaked at $0.1 \mu \mathrm{g} / \mathrm{mL} 5$ to $6 \mathrm{~d}$ postinfusion and retreated rapidly to basal levels after $10 \mathrm{~d}$. In comparison, similar treatment of nude immune-deficient mice resulted in peak FIX levels that were approximately 10 -fold higher and persisted for more than $300 \mathrm{~d}$. Different viral vectors are now being developed for use in human gene therapy. One goal is to further reduce the quantity of viral protein produced and thus limit the immune response. In one type of vector, helper-dependent adenoviral vector (HD-Ad), almost all of the adenoviral genome has been deleted, resulting in complete elimination of viral protein coding sequences (Morsy et al., 1998). This vector retains high transduction efficiency yet also elicits a diminished the host immune response. More recently, Kim et al. (2001) reported that HD-Ad mediated transfer of an apolipoprotein $\mathrm{E}$ gene into apolipoprotein Edeficient mice resulted in lifetime $(2.5 \mathrm{yr})$ correction of the hypercholesterolemia associated with the genetic defect. The toxicity associated with the treatment was negligible. Perhaps the HD-Ad system will also be appropriate for cattle. 
Our findings are in agreement with other research groups that have been exploring the vaccine potential of replication-deficient human adenovirus that has been reported to stimulate potent immune responses in mice (Xiang et al., 1996), rats (Mittal et al., 1996), cats (Gonin et al., 1995), chickens (Adam et al., 1995), monkeys (Sullivan et al., 1997), and calves (Gogev et al., 2002). The recent experiments in calves demonstrated the development of a very potent neutralizing antibody response to the antigen (bovine herpes virus-1 glycoprotein) encoded by the recombinant vector. Interestingly, the antibody response to the vector was relatively poor, even after a second immunization given $21 \mathrm{~d}$ after the first. In contrast, in our present study with mature goats, the immune response to the adenovirus itself was more rapid, more potent, and more consistent than the response to lysostaphin. Antibody titers soared between 4 and $7 \mathrm{~d}$ postinfusion. The magnitude and speed of response suggests that the goats had been preexposed to the antigen and had an existing pool of memory B cells. The doses of vector were similar between the 2 studies, although methodological differences in vector preparation might have affected potency. Other potential differences between the studies that may have contributed to the different responses are the species difference (bovine vs. goat), immunological history of the animals, and/or the site of vector administration, intranasal in the calves, intramammary in the goats. The mammary gland is a very active site of immune surveillance as evidenced by the extensive draining lymph nodes. A further difference is the persistence of shedding of transducible vector. In the calve study vector was only detected in nasal swabs in 3 of 15 inoculated animals, and then only for 1 or $2 \mathrm{~d}$. In contrast, the goat mammary secretion contained considerable vector $\left(10^{5} \mathrm{pfu} / \mathrm{mL}\right) 7 \mathrm{~d}$ postinfusion. Perhaps the thick consistency of the mammary secretion provided a depot-like effect allowing for extended time course of transduction of the epithelial cells.

\section{CONCLUSION}

Our results indicate that an adenoviral-mediated gene therapy strategy to combat mastitis is not currently feasible due to low expression persistency and potent immune responses to both the vector and the to encoded therapeutic protein. New vectors are being pursued by numerous groups for use in human gene therapy and might be of use in mastitis prevention. However, development of a strategy to avoid an immune response to the therapeutic protein itself will be a challenge. In fact, with the appropriate encoded antigen, the very potent immune response that develops after intramammary infusion of a recombinant adenoviral vector may form the basis for future vaccine development.

\section{ACKNOWLEDGMENTS}

The authors greatly appreciate Woody Pankey for his genuine support of this project. The authors also thank Fran Kinghorn, Patricia Murdough, Jane O’Neil, Rhonda Maple, and staff of the University of Vermont farm for their assistance throughout the study. Acknowledgments are made to the Northeast Dairy Foods Research Center and the Vermont Dairy Promotion Council for financial support for this study.

\section{REFERENCES}

Adam, M., W. Oualikene, H. Le Cocq, M. Guittet, and M. Eloit. 1995. Replication-defective adenovirus type 5 as an in vitro and in vivo gene transfer vector in chickens. J. Gen. Virol. 76:3153-3157.

Archer, J. S., W. S. Kennan, M. N. Gould, and R. D. Bremel. 1994. Human growth hormone (hGH) secretion in milk of goats after direct transfer of the hGH gene into the mammary gland by using replication- defective retrovirus vectors. Proc. Natl. Acad. Sci. USA 91:6840-6844.

Bramley, A. J., and R. Foster. 1990. Effects of lysostaphin on Staphylococcus aureus infections of the mouse mammary gland. Res. Vet. Sci. 49:120-121.

Chen, L. M., L. Chao, and J. Chao. 1997. Adenovirus-mediated delivery of human kallistatin gene reduces blood pressure of spontaneously hypertensive rats. Hum. Gene Ther. 8:341-347.

Clemens, P. R., S. Kochanek, Y. Sunada, S. Chan, H. H. Chen, K. P. Campbell, and C. T. Caskey. 1996. In vivo muscle gene transfer of full-length dystrophin with an adenoviral vector that lacks all viral genes. Gene Ther. 3:965-972.

Connelly, S., J. M. Gardner, A. McClelland, and M. Kaleko. 1996. High-level tissue-specific expression of functional human factor VIII in mice. Hum. Gene Ther. 7:183-195.

Connelly, S., T. A. G. Smith, G. Dhir, J. M. Gardner, M. G. Mehaffey, K. S. Zaret, A. McClelland, and M. Kaleko. 1995. In vivo gene delivery and expression of physiological levels of functional human factor VIII in mice. Hum. Gene Ther. 6:185-193.

Dai, Y., E. M. Schwarz, D. Gu, W. W. Zhang, N. Sarvetnick, and I. M. Verma. 1995. Cellular and humoral immune responses to adenoviral vectors containing factor IX gene: tolerization of factor IX and vector antigens allows for long-term expression. Proc. Natl. Acad. Sci. USA 92:1401-1405.

Daley, M. J., and E. R. Oldham. 1992. Lysostaphin: Immunogenicity of locally administered recombinant protein used in mastitis therapy. Vet. Immunol. Immunopathol. 31:301-312.

Donnelly, J. J., J. B. Ulmer, J. W. Shiver, and M. A. Liu. 1997. DNA vaccines. Annu. Rev. Immunol. 15:617-648.

Engelhardt, J. F., R. H. Simon, Y. Yang, M. Zepeda, S. Weber-Pendleton, B. Doranz, M. Grossman, and J. M. Wilson. 1993. Adenovirusmediated transfer of the CFTR gene to lung of nonhuman primates: biological efficacy study. Hum. Gene Ther. 4:759-769.

Fan, W., K. Plaut, A. J. Bramley, J. W. Barlow, and D. E. Kerr. 2002. Adenoviral-mediated transfer of a lysostaphin gene into the goat mammary gland. J. Dairy Sci. 85:1709-1716.

Gogev, S., N. Vanderheijden, M. Lemaire, F. Schynts, J. D’Offay, I. Deprez, M. Adam, M. Eloit, and E. Thiry. 2002. Induction of protective immunity to bovine herpesvirus type 1 in cattle by intranasal administration of replication-defective human adenovirus type 5 expressing glycoprotein $\mathrm{gC}$ or $\mathrm{gD}$. Vaccine 20:1451-1465.

Gonin, P., A. Fournier, W. Oualikene, A. Moraillon, and M. Eloit. 1995. Immunization trial of cats with a replication-defective adenovirus type 5 expressing the ENV gene of feline immunodeficiency virus. Vet. Microbiol. 45:393-401. 
Harmon, R. J., F. L. Schanbacher, L. C. Ferguson, and K. L. Smith. 1976. Changes in lactoferrin, immunoglobulin G, bovine serum albumin, and alpha-lactalbumin during acute experimental and natural coliform mastitis in cows. Infect. Immun. 13:533-542.

Kerr, D. E., K. Plaut, A. J. Bramley, C. M. Williamson, A. J. Lax, K. Moore, K. D. Wells, and R. J. Wall. 2001. Lysostaphin expression in mammary glands confers protection against staphylococcal infection in transgenic mice. Nat. Biotechnol. 19:66-70.

Kim, I. H., A. Jozkowicz, P. A. Piedra, K. Oka, and L. Chan. 2001. Lifetime correction of genetic deficiency in mice with a single injection of helper-dependent adenoviral vector. Proc. Natl. Acad. Sci. USA 98:13282-13287.

Lozier, J. N., M. E. Metzger, R. E. Donahue, and R. A. Morgan. 1999. Adenovirus-mediated expression of human coagulation factor IX in the rhesus macaque is associated with dose-limiting toxicity. Blood 94:3968-3975.

Mittal, S. K., Z. Papp, S. K. Tikoo, M. E. Baca-Estrada, D. Yoo, M. Benko, and L. A. Babiuk. 1996. Induction of systemic and mucosal immune responses in cotton rats immunized with human adenovirus type 5 recombinants expressing the full and truncated forms of bovine herpesvirus type 1 glycoprotein gD. Virology 222:299-309.

Morsy, M. A., M. Gu, S. Motzel, J. Zhao, J. Lin, Q. Su, H. Allen, L. Franlin, R. J. Parks, F. L. Graham, S. Kochanek, A. J. Bett, and C. T. Caskey. 1998. An adenoviral vector deleted for all viral coding sequences results in enhanced safety and extended expression of a leptin transgene. Proc. Natl. Acad. Sci. USA 95:78667871.

Nordhaug, M. L., L. L. Nesse, N. L. Norcross, and R. Gudding. 1994. A field trial with an experimental vaccine against Staphylococcus aureus mastitis in cattle. 2. Antibody response. J. Dairy Sci. 77:1276-1284.
Oldham, E. R., and M. J. Daley. 1991. Lysostaphin: Use of a recombinant bactericidal enzyme as a mastitis therapeutic. J. Dairy. Sci. 74:4175-4182.

Rosenfeld, M. A., K. Yoshimura, B. C. Trapnell, K. Yoneyama, E. R. Rosenthal, W. Dalemans, M. Fukayama, J. Bargon, L. E. Stier, and L. Stratford-Perricaudet. 1992. In vivo transfer of the human cystic fibrosis transmembrane conductance regulator gene to the airway epithelium. Cell 68:143-155.

Smith, T. A. G., M. G. Mehaffey, D. B. Kayda, J. M. Saunders, S. Yei, B. C. Trapnell, A. McClelland, and M. Kaleko. 1993. Adenovirus mediated expression of therapeutic plasma levels of human factor IX in mice. Nat. Genet. 5:397-402.

Sullivan, D. E., S. Dash, H. Du, N. Hiramatsu, F. Aydin, J. Kolls, J. Blanchard, G. Baskin, and M. A. Gerber. 1997. Liver-directed gene transfer in non-human primates. Hum. Gene Ther. 8:1195-1206.

Ulmer, J. B., J. J. Donnelly, S. E. Parker, G. H. Rhodes, P. L. Felgner, V. J. Dwarki, S. H. Gromkowski, R. R. Deck, C. M. DeWitt, and A. Friedman. 1993. Heterologous protection against influenza by injection of DNA encoding a viral protein. Science 259:1745-1749.

Xiang, Z. Q., Y. Yang, J. M. Wilson, and H. C. Ertl. 1996. A replicationdefective human adenovirus recombinant serves as a highly efficacious vaccine carrier. Virology 219:220-227.

Yang, Y., K. U. Jooss, Q. Su, H. C. Ertl, and J. M. Wilson. 1996. Immune responses to viral antigens versus transgene product in the elimination of recombinant adenovirus-infected hepatocytes in vivo. Gene Ther. 3:137-144.

Ye, X., M. B. Robinson, M. L. Batshaw, E. E. Furth, I. Smith, and J. M. Wilson. 1996. Prolonged metabolic correction in adult ornithine transcarbamylase- deficient mice with adenoviral vectors. J. Biol. Chem. 271:3639-3646. 